\title{
Culture And Risk Assessment: A Comparison Of Singapore And Taiwan
}

\author{
Shaio-Yan Huang, (E-Mail: huangsy@fcu.edu.tw), Feng Chia University, Taiwan
}

\begin{abstract}
This study examines two areas of auditing: namely, the identification of those factors that are associated with audit risk, business risk, and personal risk; and secondly how culture affects risk assessment. A factor analysis and a logistic regression are used to analyze questionnaire data collected from Singapore and Taiwan. The results show that three factors (the effectiveness of control activities, reporting bias of management and reliability of management) are strongly associated with the auditor's risk assessment. This result replicates findings of previous research, indicating the importance of understand the client's control environment in the assessment of the likelihood of material misstatements. In addition, this study also hypothesized that differences in the cultural values of Chinese auditors are likely to result in differences in the risks assessed. The results show that auditors place more emphasis on their firms' risk rather than their personal risk. However, compared to auditors in Taiwan, auditors in Singapore seem to be more concerned with risks at the individual level than at the group level. It implies the impact of Western Anglo-Saxon ideas on individuals from a Chinese background.
\end{abstract}

\section{INTRODUCTION}

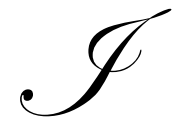

n today's expanding global economy, accounting firms serve not only local but also international companies. The increasingly complex audit procedures and the largely complicated sets of investors' portfolios have led to questions about the credibility of the auditing profession, when faced with such large risks. The challenge facing the auditor has been argued by Vinten (1991):

Auditors need to achieve a via media (middle way) between abrogating risk-taking entirely and permitting totally uncontrolled and huge risk exposures (p. 3).

Following his perspective, how much risk can an auditor bear and how can an auditor assess it? This is a difficult question to answer, and undoubtedly the answer is influenced by several factors, including the resources available and the risk-taking/avoiding propensity of the auditors.

In studying risk, the question of the adequacy of the audit risk concept was firstly addressed. It reveals that the "descriptive fidelity of existing risk models may be deficient" (Huss and Jacobs, 1991, p.19), and a call is made for a more complete model of audit risk for audit services in coping with environmental changes in the market (Kinney, 1989). Some research on the one hand has extended the concept of audit risk model to acknowledge the concept of business risk (Dejong and Smith, 1984), to include a portfolio view (Simunic and Stein, 1990) and to recognize the interrelation among three types of auditing practice risks: the client's business risk, audit risk, and the auditor's business risk (Huss, et al, 2000). Some research, on the other hand, has tended to be largely descriptive documentations of error, defalcation and fraud risk factors (Fanning, et al., 1995; Bell and Carcello, 2000; Wanda, 2000; Apostolou, et al., 2001; Walker, et al., 2001), and examines factors that lead to the risk of lawsuit (Lys and Watts, 1994; Carello and Palmrose, 1994; Ferguson and Majid, 2003). Those studies mentioned above contributed a broader view of the auditors' risk function; however, they do not investigate it in the Pacific region, nor do they address the effects of culture on the assessment of the perception of risk by auditors. In view of this, this study examines what factors affect auditors' risk assessments in the under-researched areas of Taiwan and Singapore, and to test the cultural 
effects on auditors' risk perceptions using Hofstede's cultural framework.

The reason for focusing on Singapore and Taiwan specifically is that these two countries have recognized similarities and differences. Firstly, Singapore and Taiwan both have mainly ethnically and culturally Chinese populations (78\% and 99\%, respectively). Their populations share similar values, which are rooted in the philosophy of Confucius. However, it must be expected that the differing colonial experiences of Singapore and Taiwan have lead to a change in their ways of thinking and so affect the degree of modification to the auditing standards adopted from International IFAC by Singapore and from the American Institute of Certified Professional Accountants (AICPA) by Taiwan. These changes could result in differences in the procedures of carrying out audit work. Secondly, both Singapore and Taiwan have experienced an influx of foreign business over several decades. Thirdly, family firms of small to medium size are the dominant organizational forms throughout the economy in both countries.

The study first presumes the client's control environment together with those characteristics of the client and the auditor that are likely to affect the assessed levels of auditor's risks, namely, audit risk, audit firm's business risk and auditor's personal risk. A postal questionnaire survey was used. Questions were produced based on control attributes of Haskins (1987), factors listed on SSA 6 and SSA 30 of Singapore and SAS 5 of Taiwan. A factor analysis and a logistic regression were applied. The results uncovered three factors: the effectiveness of control activities, reporting bias of management and reliability of management, which indicates the importance of the client's control environment in the assessment of the likelihood of material misstatements. In addition, four hypotheses were set in terms of Hofstede's (1994) cultural dimensions: the power distance, individualism, uncertainty avoidance and long-term orientation. The Mann-Whitney and Wilxoson tests were used to test these hypotheses. In general, the overall results do support our hypotheses that culture is a factor which affects the assessment level of risk. In other words, auditing practices are not culturally neutral.

The rest of this paper is organized as follows: The next section identifies the risk studied. The third section outlines theory and hypotheses developed, and the fourth and fifth sections present the method used and analyze the results obtained. The paper concludes with some final reflections on the results and their notion of the cultural influence on auditors' risk assessments.

\section{THEORY AND HYPOTHESES DEVELOPMENT}

\section{Risk Factors Identification}

\section{Control Environment}

Empirical evidence suggests that correctly assessing the control environment is beneficial in assessing the identified risks. Sullivan (1988) emphasized that fraudulent financial reporting is often found at the very top of the organisation - what the Treadway report (1992) called "the tone at the top" and what auditors call the control environment. A similar result was also found by Loebbeoke et al. (1989); the control environment was found to be one of the significant factors associated with management fraud. Where controls are weak, an important condition exists that can allow any of management fraud, defalcation, or an error to occur. The control environment also serves to enhance or mitigate the assessment of inherent risk and control risk (Haskins and Dirsmith, 1993; Marden et al., 1997). Accordingly, an incorrect evaluation of the control environment will lead to an incorrect assessment of inherent risk, control risk and fraud risk, and possibly result in auditing errors, such as failing to detect material errors and misstatements in the financial statements and then forming an improper opinion. An increasing likelihood of lawsuit and litigation costs can then be expected. As a result, we argue that the condition of a client's control environment is related to the risks perceived by auditors in conducting an audit engagement.

\section{Client's Characteristics}

Size always plays a major part when describing an audit client. The larger the client, the greater will be the likely number of individual elements making up the accounting systems as well as the greater the required number of formal control systems (Pierre and Anderson, 1984), and thus the greater complexity contained in those systems. 
Hence, a positive relationship between client size and potential likelihood of material mistakes being contained in the financial statements can be anticipated (Hackenbrack, 1993). Furthermore, client size is consistently associated with lawsuits because: (1) in larger companies, the damages the investors have suffered are more likely to exceed the fixed cost of suing; (2) larger companies are more likely to have the resources to pay the plaintiffs; and (3) larger companies tend to have greater insurance coverage to cover the costs of the plaintiffs' attorneys (Stice, 1991; Carcello and Palmrose, 1994; Pratt and Stice, 1994). Accordingly, the size of a client is inevitably linked to the risks that the auditors face.

\section{Auditor's Characteristics}

The name of the audit firm, especially the grouping called the "Big Five", is argued by many to be influential in contributing to the assessment of client risks. Notably, as a result of their "deep pockets" (Lennox, 1999), the Big Five firms are more able to afford to absorb higher ligitation charges or damages, which motivates litigation against auditors. Furthermore, economic losses resulting from the damage to a firm's reputation has lead the Big Five firms to be more aware of the risks that they confront. For example, Wilson and Grimlund (1990) suggested that the credibility of auditors is now under fire from the Big Six (do you mean big six or big five?) firms' clients listed by the Securities and Exchange Commission (SEC) as a result of enforcement actions. Rollins and Bremser (1997) further argued that the loss of market share was connected with the association of brand names of (Big Six) firms in the national or international auditing circles. Davis and Simon (1992) found that as a result of SEC disciplinary action, the impairment of auditors' reputations has lead to a reduction in auditing fees. As for smaller or local firms, their practice is generally performed on a personal level and regional areas so that their reputation may not suffer to the same extent from the effects of negative publicity. In a sense, the Big Five firms have more to lose than local firms when an auditing failure is alleged.

Tirole (1996) argued that a group's reputation is only as good as that of its members, and vice verse. If, in fact, a group's reputation is an aggregate of its individuals' reputations, then the degree to which an individual suffers is related to the increasing probability of the impairment of the reputation of the entire group. On the one hand, we would imagine that large accounting firms would give more attention to maintain and/or improve the quality of their personnel, in consideration of the "deep-pocket" and/or "reputation" effects - that is to say, promotion policies would be directly associated with organizational maintenance and/or improvement. Certain factors such as education level, professional certification, experience and gender have been found to have a significant influence on the promotion probability of managerial accountants (Wier and Hunton, 1995), and it is reasonable to expect that similar factors will affect the promotion probability of members in large accounting firms. On the other hand, a member who has a position of high status in an auditing firm would have a strong incentive to maintain or enhance his/her individual reputation, and by extension his/her firm's reputation.

The overwhelming picture is that the higher up in the professional hierarchy one looks, the fewer women one finds (Loft, 1992, p. 370). Consequently, a range of issues have been identified as reasons for this lack of promotion such as dual career problems (Anderson et al., 1994) and stereotyping at work (Hull and Umansky, 1997). Given the existence of gender-based obstacles to the upward mobility of women in public accounting firms, it could be argued that fewer promotion opportunities for women to higher levels will cause them to have less consideration for the risks imposed on their firms or themselves when conducting an audit engagement. Dalton, et al. (1997) found that a greater concern in turnover decision by senior personnel (ie. Partner/manager) is driven by a fear of legal liability. Implicitly, a higher position an individual occupies, a stronger sense s/he has in facing risks, and so as women tend to occupy lower positions they should be less worried by risk.

Another auditor characteristic that can be related to audit risk is the tenure of the auditor/client relationship. Pierre and Anderson (1984, p. 247) noted that "learning occurs as experience with a client increases, thereby resulting in greater efficiency in the collection and evaluation of evidence." If learning affects the efficiency and evaluation of evidence, we may assume that greater learning will bring about a greater confidence on evidential judgment and hence on the risk assessment. 
Based on the above reasoning, the following hypothesis is explored.

H1: The assessed levels of audit risk, business risk, and personal risk are subject to the evaluation of a client's control environment, the client's characteristics, and the auditor's characteristics.

\section{Hofstede's Cultural Dimensions And Risk Measures}

\section{Uncertainty Avoidance.}

This dimension refers to the degree to which the members of a society feel threatened by uncertain and ambiguous situations. In other words, people from societies with a low level of so-called 'uncertainty avoidance' have a natural tendency to feel relatively secure, and tolerate uncertainties/ambiguities. People from societies with a high level of uncertainty avoidance, on the contrary, tend to try to manage the future, because there will be a higher level of anxiety about the future. In such societies, institutions exist to create security and avoid risk. One important way to create security is through law and other formal rules, whereby protection is provided against the unpredictability of human behavior.

Hofstede's UA score for Taiwan of 69, with a ranking of twenty-six of all societies in the study, is high in comparison with Singapore, which scored 8 and was ranked fifty-three (lowest) in the study. The traits exhibited by Taiwan suggest a relatively high level of UA compared to Singapore's lower score. As indicated, the auditors' "possible future losses" being occurred is not only associated with a function of the likelihood of erroneous financial statements being issued and an audit failure being alleged (Stice, 1991), the level of risks to auditors becomes less accurately predicted and uncertain. The essence of uncertainty is that it is a subjective experience, a feeling. In Taiwan, with its high UA score, auditors are likely to be more anxious about the uncertain, unpredictable audit environment, and will endeavor to ensure and control this uncertainty or unpredictability. Auditors' attitude to the risk is considered as "significantly risk averse". In comparison, in Singapore, with its extremely low UA score, auditors have less anxiety and are more tolerant of deviant ideas. Auditors' attitude to the risk can be regarded as "slightly risk averse".

However, the great effects upon auditing firms have been observed when an audit failure is alleged, for example, the reduction of auditing fees (Davis and Simon, 1992), loss of market share (Rollins and Bremser, 1997), and loss of experienced personnel (Dalton, et al., 1997). Therefore, it is argued that to avoid risky audits, it is essential for auditors to be aware of every single risk signal.

Based on the above reasoning, the following hypothesis is explored.

H2: Auditors in both Singapore and Taiwan demonstrate a similar concern about audit risk, business risk and personal risk.

\section{Collectivism/Individualism.}

The essential issue of this dimension is associated with the degree of interdependence among individuals the society maintains. People in an individualist culture are expected to act according to their own interest and their own needs. In a collectivist culture, people will act according to the interest of the so-called 'ingroup'. In both Singapore and Taiwan, the majority of the population is ethno-culturally Chinese, and it is the group rather than the individual that is important since the family is the core of society and is the single most important unit. A workplace in a collectivist society may become an ingroup and resemble a family relationship with mutual obligations of protection in exchange for loyalty. Individuals will be concerned about the reputation of their ingroup rather than themselves. The auditors' assessment of business risk compared to personal risk can be seen as a reflection of the auditors' interest in their ingroup as opposed to their own. In a collectivist society like Singapore and Taiwan, the concept of the best performance operates as a group goal, and anonymously (Hofstede, 1994, p. 65). Hence, an auditor seems to be more concerned about the auditing firm rather than the individual. However, it is commonly known that business in Chinese-dominant societies is transacted in the context of interpersonal relationships, with a relationship simply established on the basis of interpersonal trust. A concept that is related to (interpersonal) trust is that of "reputation". A 
trustworthy person is a person who has a "reputation for trustworthiness" (Evers, 1993, p.133). Consequently, information about an individual's reputation in the Chinese business world is the criteria for one to generate trust. A good reputation increases trustworthiness. In addition, there is a close relationship between the group's reputation and the individual's reputation (Tirole, 1996; Fiol et al., 2001). The group's reputation is derived from the individual's reputation of its members, and vice versa (Tirole, 1996). These upward and downward transfers of reputation (Fiol et al., 2001) reflect their reputational interdependence, and stimulate the group and its individual members to sustain a good reputation for each others' sake. Accordingly, it is argued that auditors in an auditing firm are concerned about their firm and themselves at the same time.

Based on the above reasoning, the following hypothesis is explored.

H3: Within the individual countries of Singapore and Taiwan, auditors will demonstrate a similar concern about business risk and personal risk.

\section{METHOD}

\section{Participants}

The primary aims of this study are to discover how auditors assess risks and if auditing is culturally neutral. All sizes of auditing firms therefore were included in the survey. Participants included 104 auditors from Singapore, each with an average experience of 5.8 years, and 147 Taiwanese auditors participated, each with an average experience of 5.5 years.

\section{Questionnaire Design}

The survey instrument consisted of a questionnaire which contained three major categories: client profiles, audit risk factors and respondent profiles. Details of the questions included in the questionnaire are shown in the Appendix and a brief description of independent variables and their abbreviations used in the study are presented in Table 1.

\section{Client Profiles}

In this section, the respondent was asked to select their "example audit client" and then to give some information about their example client such as ownership, size, and tenure of the audit firm. The "example audit client" refers to the client chosen as the largest audit client by the respondent from his or her client portfolio in 1999.

\section{Audit Risk Factors}

In this section, the respondent was asked to assess nineteen risk factors predominantly related to the control environment based on three sources: (1) the more important control attributes of Haskins (1987), (2) factors listed in both SSA 6 and SSA 30 of Singapore, and (3) factors listed in SAS 5 of Taiwan. Afterwards, the respondent was asked to assess the audit risk, business risk and personal risk presented by the example audit client.

\section{Respondent Profiles}

This section asked respondents to give details about their age, sex, degree, years of auditing experience, position in their audit firm, language they speak, how long they had been a CPA and the proportion of the working week they spent on auditing. 


\section{Language Of The Questionnaire}

Having created the questionnaire in English, there was then the issue of what language to use in Taiwan and Singapore. In Taiwan, the only official language is Mandarin Chinese; therefore, the "back translation" technique was used. The English version of the questionnaire was translated completely into Chinese by four post-graduate students. Two students prepared a translation of the questionnaire, compared their translations, and then discussed all discrepancies. A third student was asked to translate the Chinese questionnaire back into English, and compare them with the originals. The fourth student looked at any discrepancies in translation and discussed the final Chinese translation with the author. For Singapore, however, it was decided not to use the Chinese version of the questionnaire for a number of reasons. Firstly, it is mandatory for ethnic Chinese, but optional for other ethnic groups, to study Mandarin. Another difficulty is that there are two types of Chinese characters used in writing: a traditional set and a simplified set. Whereas in Taiwan, the population has always used the traditional set, in Singapore, the simplified set has been adopted relatively recently, creating a rift in Chinese literacy between those who more readily know traditional characters, and those who more readily recognize the simplified ones. In addition, Though Mandarin may gradually become more important, the Singaporean Chinese themselves see the importance of English as a commercial language, and all can read it reasonably well.

\section{Methods Of Data Analysis Employed}

\section{Factor Analysis Of Independent Variables}

Preliminary data analysis related to computing correlations among the dependent variables (DVs) and independent variables (IVs) was undertaken to examine for potential problems relating to multicollinearity. Table 2 demonstrates that the highest correlation coefficient was .790, showing that collinearity should not be a significant problem between variables for the Taiwan sample, as it only becomes a serious problem when the coefficient is higher than 0.90 (Tabachnick and Fidell, 2001, p.82). Table 3 indicates collinearity to be presented for the Singapore sample as the highest correlated coefficient between variable TAST and TSALE is .929. Therefore, the variable TSALE is deleted from the factor analyses. Such a deletion was made following the argument outlined by Low, et al (1990) that the definition of sales may vary among entities which results in comparability problems.

An exploratory factor analysis was performed to regroup independent variables and hereafter those generated factors will be renamed and used as the independent variables in the following logistic regression models for risk assessments. Table 4 shows that eight factors were produced for Taiwan whereas table 5 shows seven factors were produced for Singapore.

\section{Logistic Regression Model}

as:

According to the factor analysis result showed in table 4 and table 5, the regression equation takes the form

\footnotetext{
Identified risk $=f($ factor $1+$ factor $2+$ factor $3+$ factor $4+$ factor $5+$ factor $6+$ factor $7+$ factor 8$) \ldots($ Taiwan $)$

Identified risk $=f($ factor $1+$ factor $2+$ factor $3+$ factor $4+$ factor $5+$ factor $6+$ factor 7$) \ldots($ Singapore $)$
}

Three regressions were run for each country for the three forms of identified risk, namely: audit risk, business risk and personal risk. 


\begin{tabular}{|l|l|l|}
\hline \multicolumn{1}{|c|}{ Factor } & \multicolumn{1}{c|}{ Taiwan } & \multicolumn{1}{c|}{ Singapore } \\
\hline Factor 1 & effectiveness of control activities & Effectiveness of control activities \\
\hline Factor 2 & maturity of respondent & Maturity of respondent \\
\hline Factor 3 & effectiveness of environmental monitoring & $\begin{array}{l}\text { Extent of check on financial personnel and } \\
\text { environmental monitoring }\end{array}$ \\
\hline Factor 4 & reporting bias of management & Large audit firm environment \\
\hline Factor 5 & size of client & Reporting bias of management \\
\hline Factor 6 & reliability of management & Reliability of management \\
\hline Factor 7 & extent of check on finance personnel & Percentage of the respondent's time auditing \\
\hline Factor 8 & size of the audit firm & ----------- \\
\hline
\end{tabular}

Therefore, the hypothesis is restated and re-written as follows:

H1T: The assessed levels of audit risk, business risk, and personal risk are influenced by the effectiveness of control activities, the maturity of respondents, the effectiveness of environmental monitoring, the reporting bias of management, the size of the client, the reliability of management, the extent of the check on finance personnel, and the size of the auditing firm.

H1S: The assessed levels of audit risk, business risk and personal risk are influenced by the effectiveness of control activities, the maturity of respondents, the extent of the check on financial personnel and environmental monitoring, the large auditing firm environment, the reporting bias of management, the reliability of management and the percentage of the time respondents spend auditing.

\section{RESULTS}

\section{Logistic Results For Taiwan}

\section{Results For Audit Risk}

Table 6 shows that there were three significant $(\mathrm{p}<0.5)$ factors: the effectiveness of control activities, the reporting bias of management, and the reliability of management. Not surprisingly, the effectiveness of controls plays a key role as they help prevent mistakes from occurring in the financial statements. Hence, it would be expected that the more effective control activities are, then the lower the level of audit risk will be set. In addition, the assessed level of audit risk was also found to be influenced by the degree of the reporting bias of management. The greater the desires and opportunities for management to bias the annual accounts, the higher the likelihood that material mistakes will remain undiscovered in the financial statements, and hence, the higher the level of audit risk that will be assessed. This result is consistent with the requirement in SAS No. 5 of Taiwan: 'Investigation and Appraisal of Internal Accounting Control' which states that the auditor has to consider management integrity and honesty when evaluating the existence of those internal accounting control defaults, that could cause material errors or irregularities. Furthermore, the reliability of management is also one of the key factors in explaining the changes of audit risk. The negative sign indicates that the higher the reliability of management, the fewer the expected number of material mistakes will be. Auditing evidence is more reliable when the management of the client can be trusted. If the reliability of management is suspect, then the information contained in the financial statements will become questionable.

\section{Results For Business Risk}

Table 7 shows those factors that were significant in the assessment of audit risk were also found to be significant in the assessment of business risk. The negative sign for Factor One: "effectiveness of control activities" indicates that the level of business risk will be reduced when control activities are seen as being more effective. Conversely, weaker controls should lead to a greater chance of material errors being made and undetected. The positive sign for Factor Four: "reporting bias of management" shows that business risk is expected to be greater when management has a greater tendency to bias the financial statements. Factor Six: "reliability of management" is also 
found to be significantly negative, suggesting that business risk is greater when management is seen as being less reliable. Both factors: "management reporting bias" and "management reliability" found to be significant indicating Taiwanese auditors' concern for the possibility of management override of financial reporting controls. Taking the view of Palmrose (1987), management fraud is:

an intentional misrepresentation involving upper-level executives and either perpetrated or covered up through fraudulent (materially misleading) financial reporting to outside users (p. 97).

According to her definition, factors of management reporting bias and management reliability are associated with the occurrence of management fraud. As pointed out by Palmrose (1987), management fraud plays a major role in the incidence of litigation against independent auditors. Therefore, it is not surprising that auditors in Taiwan take account of these two factors when they evaluate business risk.

\section{Results For Personal Risk}

Those factors explaining the variance of the assessment of audit risk and business risk were found again in Table 8 to be significant at the 0.02 level for personal risk. The significant negative coefficient on Factor One suggests that greater effective controls are associated with lower personal risk. The significant positive coefficient on Factor Four suggests that the reporting bias of management is associated with the assessment of personal risk. The more chances management will bias the financial reports, the greater the personal risk of the auditor. The significance of Factor Six suggests that the assessment of personal risk is influenced by the reliability of management. The negative coefficient indicates that the more reliable management is, the lower the personal risk of the auditor. It is not surprising that auditors evaluate the factors which have impacts on the assessment of business risk that also have the same influence upon the assessment of personal risk. One reason may be because the sanctioned subject of the CPA Disciplinary Committee of Ministry of Finance of Taiwan (is CPA personally - Clive - I don't understand these 3 words together in this context). An alternative may be possibly referred to the phenomenon that the number of sanctioned cases was sharply increasing within the period of 1991 and 1996. This happened because a large number of bankruptcies of listed companies had threatened the capital market in Taiwan between the years of 1988 and 1990. In order to strengthen and improve such a situation, specific attention was brought to the concern of auditing quality. Therefore, Taiwanese auditors with a strong awareness of being sanctioned paid great attention to the risk of damaging their personal reputation.

\section{Logistic Results For Singapore}

\section{Results For Audit Risk}

Table 9 presents the logistic results of the regression of audit risk against seven factors resulting from both client and auditor characteristics together with nineteen inherent and control risk factors. The results show that factor one, 'Effectiveness of control activities', was found to be the most significant factor $(\mathrm{p}<.03)$ relating to the variance of audit risk assessment. This finding indicates the concern of auditors about the fundamental internal control activities in relation to audit risk in accordance with the existing literature and the SSA No. 11 of Singapore, "Fraud and Error" (ICPAS, 1995). However, the positive sign is a puzzle. The variables loaded on the factor relate to how effective the client's control activities are. Hence the result seems to imply that the better the control environment, the greater the audit risk. In order to gain an understanding of what variables in Factor One caused this unexpected sign direction, the chi-square test was used to see the association between audit risk and each variable. The results show that three areas (the internal audit function, the financial function and the segregation of duty) are strongly associated with higher audit risk regardless of their goodness $(\mathrm{p}<0.05)$.

Such extraordinary phenomena, pointed out by a manager from one of the Big Five firms in Singapore, might be related to the ever-present effect of Barings' collapse. In the case of Barings, the internal auditors had picked up some indication of the control crisis and precisely recommended the separation of the front and back office roles which were both undertaken by Nick Leeson (Kane and DeTrask, 1999, p. 210). However, their recommendation was restrained but never implemented, and the external auditors subsequently determined the company's controls 
acceptable.

Following the collapse of Barings, criticism placed upon its external auditors [Coopers \& Lybrand (C \& L) Singapore] was related to their failure to notice the 'absolute failure' of Barings internal control. Firstly, the auditors of C \& L Singapore failed to be conscious of the insufficient organisational status and independence of internal audits of Barings since it had been kept from them. C \& L Singapore had concluded that the BFS's controls were satisfactory. However, this conclusion is not consistent with the fact of an existence of improper segregation between the front and back office, and this was so whether or not Barings' internal auditor had noticed. Secondly, C \& L Singapore apparently failed to consider the possibility of fraud in terms of its audit failures on: (1) controlling the confirmation process, (2) accepting photocopied or facsimiled documentation and (3) reviewing the transactions recorded in the error account (Simon, 1996, p. 39). C \& L Singapore should have been more alert to the likelihood of fraud since a $£ 50 \mathrm{~m}$ discrepancy in the accounts was discovered. The auditors were criticised by their acceptance of Leeson's explanation about the "hole" in the balance sheet which was subject to receipt of supporting documentation, including confirmation of the transaction directly from Spear, Leeds and Kellogg (SLK).

The reality of material mistakes in the Barings' financial statements draws lessons for the auditors. Chiefly, that internal audits are valuable and effective when given sufficient status and independence, and their recommendations are properly and promptly acted upon. If this is not the case, the auditors should take a skeptical view; one that there is always the possibility of material mistakes in the financial statements whenever the internal audit has observed the control weaknesses of its organisation or not. Another lesson to be spotlighted is that the operation of an organisation could be led entirely by a single individual, especially one who occupies a position of top management. As to the phenomena indicated by Kane and DeTrask (1999) on Barings' collapse, Leeson had too dominant a role in the trading and settlements business of the Singapore operation and his direct supervisor left him "to his own devices". As a result, the senior clerks would not likely speak up if something was amiss in Singapore (p. 211). These episodes direct a belief that the concealment of material mistakes in the financial statements may still happen when there exists a clear segregation of duties among lower-level employees, and when a national culture facilitates a climate of unquestioning obedience. Accordingly, a common effect of Barings' scandal on Singapore auditors is that they might take a reserved attitude in assessing the level of audit risk. (There is, a reduction of audit risk is not been made when a good internal function and a clear segregation of duties exist, and a suspicion of high possibility of material mistakes in the financial statements even remains on the auditor's mind. Clive - I'm not sure what to do with this; it's very awkward. Possibly, "That is to say, even with good internal functions and a clear segregation of duties, and even with a suspicion of material mistakes on the financial statements, a reduction of audit risk has not been made." But even this, Clive, is very strange indeed in this context. Consider revising) This might explain the "puzzle" of the positive relationship between the assessment of audit risk and the effectiveness of control activities.

\section{Results For Business Risk}

The logistic regression results (Table 10) show that there were no significant factor variable coefficients at the 0.10 level when using business risk as the dependent variable. The results indicate that neither inherent and control risk factors nor auditor characteristics used in this study have influential impacts on the assessment of business risk. These findings were consistent with expectations based on Hofstede work. Hofstede's (1984) uncertainty-avoidance results showed that Singapore has the lowest uncertainty avoidance index and extremely high power distance index which result in very low risk perceptions. In addition, the amount of litigation against auditors in Singapore is not as prevalent as in the US and in the UK. Up to date, there are no formal records of local lawsuit cases in Singapore. The only filing litigation against an auditor was held in 1988 by the liquidator of Pan-Electric Industries Ltd against the company's former auditor, accused of breach of duty to shareholders. However, the case was settled out of court (Arens, et al, 1997, p. 77). This may explain why auditors in Singapore are more relaxed when facing their firms' business risk. The other explanation may be related to the exclusion of other risk factors or the auditor's personality to risk which might affect the risk assessments - but those are not the concerns of this study. 


\section{Results For Personal Risk}

From the logistic regression results reported in Table 11, it can be seen that Factor One: 'Effectiveness of control activities' again has the greatest level of significance (significant at $5 \%$ level) on the personal risk assessment, but with a negative sign. This unexpected relation, alternatively, is investigated by a conduct of chi-square test between audit risk and variables grouped in Factor One. The results indicate that both internal audit function and financial function are significantly associated with the assessment of personal risk at the level of 0.05 , which are similar to the results found for the audit risk. These findings reflect that auditors of Singapore learned from C \& $\mathrm{L}$ Singapore's audit failure on the Barings, and hence affected on their continuous audit practice. Therefore, the reasons to explain the positive relationship between audit risk and Factor One: 'Effectiveness of control activities' can be also applied to explain the positive relationship between personal risk and Factor One.

\section{Results For Cross-Cultural Risk Assessment Comparison}

To test the second hypothesis, the Mann Whitney analysis of variance was applied. Table 12 shows that there was no significant difference in the level of audit risk and personal risk assessed by the auditor in Singapore and in Taiwan $(Z=-.669, p>0.05$ and $Z=-0.240, p>0.05)$. However, there was a slight difference (where $Z=-1.860, p$ $=0.063$ ) in the level of business risk assessed by the auditor in Singapore and in Taiwan. Our explanation of this weak significant difference in business risk assessment is that in Singapore, with its continuous Westernization, the hiring of staff is based on merit rather than on relationship to owners (Lee, 1996), and more emphasis has been placed on expertise and professional relationships. This leads individuals in Singapore to be more concerned about personal development and achievement rather than a group commitment. Singapore shows a move towards a more individualistic society (Lee, 1996). By contrast, in Taiwan, a relatively typical Chinese society, the hiring process always takes the ingroup into account. The person being hired is usually from a family one already knows and trusts and the position of top management is often assigned to family members. Therefore, individuals in Taiwan have a tendency to group goal and development and a concern with reputation of group. This results in a more collective society. Such analyses lead us to reject our hypothesis $\mathrm{H} 2$ that both auditors perceived equal assessment of audit risk, business risk and personal risk.

To test the third hypothesis, the Wilcoxon test was applied. Table 13 indicates that auditors in Singapore $(\mathrm{Z}=-4.594, \mathrm{p}<0.05)$ and Taiwan $(\mathrm{Z}=-3.464, \mathrm{p}<0.05)$ assessed the risk that their firm might face and the risk that s/he personally might face differently. It means that auditors in both countries had different interests at the group level and at the individual level. This allows us to reject our hypothesis $\mathrm{H} 3$ that both auditors perceived equal importance at a personal risk and a business risk level.

\section{DISCUSSION AND CONCLUSION}

With an increasing threat to auditors under the current litigation environment, an important issue relating to how auditors can cope remains to be answered. Of special interest is if auditors in the Far East conduct their work on risk assessment as well as their counterparts from countries that subscribe to so-called 'Western Culture', if Chinese culture with its predominant features distinguishes itself from Western culture, which has influenced the auditing work examined in this study.

Regarding the examination of what factors have an effect on risk assessment, the regression results indicate that for both Taiwan and Singapore, overall, there are three factors found to have significant explanatory power: (1) the effectiveness of control activities, (2) reporting bias of management and (3) reliability of management. This suggests that the control environment of a client is a key factor in explaining the variability of the auditors' risk assessments. Therefore, on the basis of the evidence presented, it is concluded that the first hypothesis for Taiwan and Singapore (H1T and H1S) could not be rejected.

With respect to the effect of culture on assessed level of risks, a weak significance in the assessment of business risk was found by the Mann-Whitney U test. It reflects that auditors in Singapore are more interested in self-development rather than group participation in comparison with auditors in Taiwan. The explanation offered here 
is related to Singapore's English-speaking influence and its continuous Westernization. Both elements are gradually influencing Singapore to move away from "Asian ways" towards "Western ways". This means the concept of societal collectivism in Singapore is slowly being replaced by the concept of individualism, even though Singapore's "core value campaign" is based on Confucianism, which provides a source to cope with all sorts of "negative" effects of modernity such as "excessive individualism" (Evers, et al., 1993). It is thus expected that in Singapore, auditors will likely place more concern upon their own individual reputations and the risk of damage thereupon. Thus the evidence of the study does not support the second hypothesis $(\mathrm{H} 2)$. One further finding of the study was that there is a significant difference in the assessment of business risk and personal risk among auditors for both countries $(\mathrm{p} \leq .0001)$ This result does therefore not support the third hypothesis (H3).

In conclusion, it would appear from the evidence of the postal questionnaire that the client's control environment is a significant explanatory variable when assessing audit, business and personal risk. In particular, the factors relating to the effectiveness of control activities, management reporting bias and management reliability dominate these three risks' assessments. However, the failure to discover the relationship between risk assessment and auditor characteristics might have less explanatory power over the assessment of engagement risk found in the Western countries. Future research could shed light on the investigation of this inconsistent result. Moreover, it would extend analysis to consider "other attributes" of control environment excluded from this study. In addition, the testing results for $\mathrm{H} 2$ and $\mathrm{H} 3$ are consistent with the findings by Arnold, et al. (2001), indicating that culture is a factor in varying risk assessment levels. In other words, the risk assessment is not culturally neutral and revolutions in culture(s) will be integrated into daily auditing practices. Hence, the awareness of gradual cultural change is of crucial importance for researchers.

Table 1

Summary of Independent Variables for Input into the Audit, Business and Personal Risk Regression

\begin{tabular}{|c|c|c|c|c|}
\hline \multicolumn{2}{|c|}{ Control Variables } & \multirow{2}{*}{\multicolumn{3}{|c|}{$\begin{array}{l}\text { AR BR PR } \\
\text { Predicted Sign }\end{array}$}} \\
\hline Abbreviation & Definition & & & \\
\hline CA1 & There is an appropriate policy for the authorisation of transactions & - & - & - \\
\hline CA2 & There is appropriate segregation of duties for client employees whose work is related to financial matters & - & - & - \\
\hline CA3 & There are effective general Computer Information Systems (CIS) controls & - & - & - \\
\hline CA4 & There are effective physical safeguards over assets & - & - & - \\
\hline CA5 & There is effective co-ordination between different financial functions (e.g. sales, purchases, cash, etc.) & - & - & - \\
\hline CA6 & There are appropriate procedures for the review of variances from budgeted performance & - & - & - \\
\hline CA8 & There are appropriate duties and responsibilities assigned to the internal auditors & - & - & - \\
\hline CA9 & The internal auditors are effective at remedying weaknesses in internal control & - & - & - \\
\hline CA10 & $\begin{array}{l}\text { There are strong factors that might motivate senior management to override existing controls (e.g. tight credit, } \\
\text { low working capital, bonus plans, need to meet forecasts, declining industry, etc.) }\end{array}$ & + & + & + \\
\hline CA11 & The rate of turnover of senior management has been low in the last three years & - & - & - \\
\hline CA12 & The client's senior management has a good business reputation & - & - & - \\
\hline CA14 & The client's major operating decisions are usually made by just one or two individuals & + & + & + \\
\hline CA15 & The client usually investigates the background of new employees whose work is related to financial matters & - & - & - \\
\hline CA16 & There are appropriate training programmes for employees whose work is related to financial matters & - & - & - \\
\hline CA17 & The client is effective at monitoring competitors' activities & - & - & - \\
\hline CA18 & The client is effective at monitoring changes in customer requirements & - & - & - \\
\hline CA19 & The audit process usually produces changes in the client's draft financial statements & - & - & - \\
\hline TAST & Client size & + & + & + \\
\hline TSALE & Client size & + & + & + \\
\hline LISTD & Whether client lists on the Stock Exchange & + & + & + \\
\hline CYINV & Tenure of auditor/client relationship & $?$ & - & - \\
\hline Age & How old the auditor is & $?$ & + & + \\
\hline Sex & Which gender the auditor is & $?$ & + & + \\
\hline WKY & How many years of auditing experience the auditor has & $?$ & + & + \\
\hline PART & The auditor's position & $?$ & + & + \\
\hline CPAY & The length of being a CPA & $?$ & + & + \\
\hline
\end{tabular}


Table 2

Correlation Matrix of Audit Risk, Business Risk, Personal Risk, Client and Auditor Characteristics by Taiwan

\begin{tabular}{|c|c|c|c|c|c|c|c|c|c|c|c|c|c|}
\hline & $\mathrm{BR}$ & PR & LISTD & TAST & TSALE & CYINV & AGE & SEX & WKY & PART & CPAY & ATMP & BIG 5 \\
\hline$\overline{\mathrm{AR}}$ & $\begin{array}{c}.762 \\
(.000)\end{array}$ & $\begin{array}{c}598 \\
(.000)\end{array}$ & $\begin{array}{l}-.141 \\
(.097)\end{array}$ & $\begin{array}{l}-.130 \\
(.125)\end{array}$ & $\begin{array}{l}-.138 \\
(.102)\end{array}$ & $\begin{array}{l}-.098 \\
(.246)\end{array}$ & $\begin{array}{c}.033 \\
(.696)\end{array}$ & $\begin{array}{c}.032 \\
(.707)\end{array}$ & $\begin{array}{c}.070 \\
(.411)\end{array}$ & $\begin{array}{c}.035 \\
(.683)\end{array}$ & $\begin{array}{l}-.084 \\
(.320)\end{array}$ & $\begin{array}{c}.050 \\
(.561)\end{array}$ & $\begin{array}{l}.052 \\
(.539)\end{array}$ \\
\hline BR & & $\begin{array}{l}.720 \\
(.000)\end{array}$ & $\begin{array}{l}-.094 \\
(.270)\end{array}$ & $\begin{array}{l}-.028 \\
(.740)\end{array}$ & $\begin{array}{l}-.072 \\
(.394)\end{array}$ & $\begin{array}{l}-.167 \\
(.048)\end{array}$ & $\begin{array}{c}.024 \\
(.782)\end{array}$ & $\begin{array}{l}.101 \\
(.233)\end{array}$ & $\begin{array}{l}.003 \\
(.974)\end{array}$ & $\begin{array}{c}.099 \\
(.243)\end{array}$ & $\begin{array}{l}-.028 \\
(.744)\end{array}$ & $\begin{array}{l}-.070 \\
(.413)\end{array}$ & $\begin{array}{c}.066 \\
(.436)\end{array}$ \\
\hline PR & & & $\begin{array}{c}-.175 \\
(.039)\end{array}$ & $\begin{array}{l}-.137 \\
(.106)\end{array}$ & $\begin{array}{l}-.110 \\
(.194)\end{array}$ & $\begin{array}{l}-.028 \\
(.740)\end{array}$ & $\begin{array}{c}-.113 \\
(.184)\end{array}$ & $\begin{array}{c}.074 \\
(.387)\end{array}$ & $\begin{array}{c}.073 \\
(.389)\end{array}$ & $\begin{array}{l}.116 \\
(.172)\end{array}$ & $\begin{array}{l}-.019 \\
(.824)\end{array}$ & $\begin{array}{l}-.025 \\
(.767)\end{array}$ & $\begin{array}{c}.072 \\
(.397)\end{array}$ \\
\hline LISTD & & & & $\begin{array}{l}.516 \\
(.000)\end{array}$ & $\begin{array}{c}.453 \\
(.000)\end{array}$ & $\begin{array}{l}-.090 \\
(.292)\end{array}$ & $\begin{array}{l}-.026 \\
(.759)\end{array}$ & $\begin{array}{c}.091 \\
(.289)\end{array}$ & $\begin{array}{l}-.008 \\
(.923)\end{array}$ & $\begin{array}{l}-.049 \\
(.564)\end{array}$ & $\begin{array}{c}.082 \\
(.333)\end{array}$ & $\begin{array}{l}-.082 \\
(.336)\end{array}$ & $\begin{array}{c}.093 \\
(.273)\end{array}$ \\
\hline TAST & & & & & $\begin{array}{c}.779 \\
(.000)\end{array}$ & $\begin{array}{c}.032 \\
(.708)\end{array}$ & $\begin{array}{c}.000 \\
(.999)\end{array}$ & $\begin{array}{l}.187 \\
(.027)\end{array}$ & $\begin{array}{l}.046 \\
(.590)\end{array}$ & $\begin{array}{c}.018 \\
(.832)\end{array}$ & $\begin{array}{l}.188 \\
(.025)\end{array}$ & $\begin{array}{l}.112 \\
(.186)\end{array}$ & $\begin{array}{l}.137 \\
(.106)\end{array}$ \\
\hline TSALE & & & & & & $\begin{array}{l}.057 \\
(.503)\end{array}$ & $\begin{array}{c}.031 \\
(.717)\end{array}$ & $\begin{array}{c}.193 \\
(.023)\end{array}$ & $\begin{array}{c}.044 \\
(.606)\end{array}$ & $\begin{array}{c}.042 \\
(.620)\end{array}$ & $\begin{array}{c}.277 \\
(.001)\end{array}$ & $\begin{array}{l}.105 \\
(.216)\end{array}$ & $\begin{array}{c}.222 \\
(.008)\end{array}$ \\
\hline CYINV & & & & & & & $\begin{array}{l}.525 \\
(.000)\end{array}$ & $\begin{array}{c}.200 \\
(.018)\end{array}$ & $\begin{array}{c}.658 \\
(.000)\end{array}$ & $\begin{array}{c}.332 \\
(.000)\end{array}$ & $\begin{array}{c}.211 \\
(.012)\end{array}$ & $\begin{array}{l}-.220 \\
(.009)\end{array}$ & $\begin{array}{l}-.192 \\
(.022)\end{array}$ \\
\hline AGE & & & & & & & & $\begin{array}{c}.412 \\
(.000)\end{array}$ & $\begin{array}{c}.790 \\
(.000)\end{array}$ & $\begin{array}{l}.458 \\
(.000)\end{array}$ & $\begin{array}{c}.317 \\
(.000)\end{array}$ & $\begin{array}{l}-.330 \\
(.000)\end{array}$ & $\begin{array}{l}-.238 \\
(.004)\end{array}$ \\
\hline SEX & & & & & & & & & $\begin{array}{c}.261 \\
(.002)\end{array}$ & $\begin{array}{c}.271 \\
(.001)\end{array}$ & $\begin{array}{l}.205 \\
(.015)\end{array}$ & $\begin{array}{l}-.267 \\
(.002)\end{array}$ & $\begin{array}{c}.034 \\
(.690)\end{array}$ \\
\hline WKY & & & & & & & & & & $\begin{array}{c}.485 \\
(.000)\end{array}$ & $\begin{array}{c}.333 \\
(.000)\end{array}$ & $\begin{array}{l}-.283 \\
(.001)\end{array}$ & $\begin{array}{c}-.208 \\
(.013)\end{array}$ \\
\hline PART & & & & & & & & & & & $\begin{array}{c}.579 \\
(.000)\end{array}$ & $\begin{array}{l}-.180 \\
(.034)\end{array}$ & $\begin{array}{l}-.125 \\
(.140)\end{array}$ \\
\hline CPAY & & & & & & & & & & & & $\begin{array}{l}-.151 \\
(.076)\end{array}$ & $\begin{array}{l}.100 \\
(.236)\end{array}$ \\
\hline ATMP & & & & & & & & & & & & & $\begin{array}{l}.245 \\
(.004)\end{array}$ \\
\hline
\end{tabular}

* The first number listed is the correlation; the number in parentheses is the significance level

Table 3

Correlation Matrix of Audit Risk, Business Risk, Personal Risk, Client and Auditor Characteristics by Singapore

\begin{tabular}{|c|c|c|c|c|c|c|c|c|c|c|c|c|c|}
\hline & BR & PR & $\begin{array}{l}\text { LISTD } \\
\end{array}$ & TAST & TSALE & CYINV & AGE & SEX & WKY & $\begin{array}{l}\text { PART } \\
\end{array}$ & CPAY & ATMP & BIG 5 \\
\hline AR & $\begin{array}{l}.706 \\
(.000)\end{array}$ & $\begin{array}{c}.480 \\
(.000)\end{array}$ & $\begin{array}{l}.007 \\
(.943)\end{array}$ & $\begin{array}{l}-.045 \\
(.668)\end{array}$ & $\begin{array}{l}-.015 \\
(.881)\end{array}$ & $\begin{array}{l}-.069 \\
(.504)\end{array}$ & $\begin{array}{c}-.041 \\
(.690)\end{array}$ & $\begin{array}{c}.059 \\
(.573)\end{array}$ & $\begin{array}{c}-.047 \\
(.646)\end{array}$ & $\begin{array}{c}-.041 \\
(.690)\end{array}$ & $\begin{array}{c}-.069 \\
(.504)\end{array}$ & $\begin{array}{c}.156 \\
(.128)\end{array}$ & $\begin{array}{c}.063 \\
(.541)\end{array}$ \\
\hline BR & & $\begin{array}{c}.494 \\
(.000)\end{array}$ & $\begin{array}{c}.020 \\
(.850)\end{array}$ & $\begin{array}{l}.051 \\
.624)\end{array}$ & $\begin{array}{c}.002 \\
(.988)\end{array}$ & $\begin{array}{l}.120 \\
(.245)\end{array}$ & $\begin{array}{l}-.026 \\
(.802)\end{array}$ & $\begin{array}{c}.033 \\
(.754)\end{array}$ & $\begin{array}{c}.000 \\
(1.000)\end{array}$ & $\begin{array}{c}.028 \\
(.787)\end{array}$ & $\begin{array}{l}-.009 \\
(.929)\end{array}$ & $\begin{array}{c}.023 \\
(.827)\end{array}$ & $\begin{array}{l}-.011 \\
(.917)\end{array}$ \\
\hline PR & & & $\begin{array}{c}.082 \\
(.425)\end{array}$ & $\begin{array}{l}-.133 \\
(.200)\end{array}$ & $\begin{array}{l}-.107 \\
(.301)\end{array}$ & $\begin{array}{l}.223 \\
(.029)\end{array}$ & $\begin{array}{c}.110 \\
(.287)\end{array}$ & $\begin{array}{c}.000 \\
(1.000)\end{array}$ & $\begin{array}{c}.059 \\
(.570)\end{array}$ & $\begin{array}{l}-.640 \\
(.536)\end{array}$ & $\begin{array}{c}.116 \\
(.261)\end{array}$ & $\begin{array}{l}-.152 \\
(.140)\end{array}$ & $\begin{array}{l}-.010 \\
(.926)\end{array}$ \\
\hline LISTD & & & & $\begin{array}{c}.583 \\
(.000)\end{array}$ & $\begin{array}{l}.667 \\
(.000)\end{array}$ & $\begin{array}{l}-.007 \\
(.948)\end{array}$ & $\begin{array}{l}-.062 \\
(.550)\end{array}$ & $\begin{array}{c}.037 \\
(.720)\end{array}$ & $\begin{array}{l}.101 \\
(.329)\end{array}$ & $\begin{array}{l}-.040 \\
(.699)\end{array}$ & $\begin{array}{l}.146 \\
(.157)\end{array}$ & $\begin{array}{l}-.108 \\
(.293)\end{array}$ & $\begin{array}{c}.690 \\
(.000)\end{array}$ \\
\hline TAST & & & & & $\begin{array}{c}.929 \\
(.000)\end{array}$ & $\begin{array}{l}.048 \\
(.647)\end{array}$ & $\begin{array}{l}.0900 \\
(.390)\end{array}$ & $\begin{array}{l}.177 \\
(.090)\end{array}$ & $\begin{array}{l}.186 \\
(.073)\end{array}$ & $\begin{array}{l}.156 \\
(.134)\end{array}$ & $\begin{array}{l}.240 \\
(.020)\end{array}$ & $\begin{array}{l}-.062 \\
(.550)\end{array}$ & $\begin{array}{c}.654 \\
(.000)\end{array}$ \\
\hline TSALE & & & & & & $\begin{array}{l}.021 \\
(.838)\end{array}$ & $\begin{array}{c}.076 \\
(.463)\end{array}$ & $\begin{array}{l}.185 \\
(.073)\end{array}$ & $\begin{array}{c}.224 \\
(.028)\end{array}$ & $\begin{array}{c}.084 \\
(.416)\end{array}$ & $\begin{array}{c}.217 \\
(.033)\end{array}$ & $\begin{array}{l}-.034 \\
(.744)\end{array}$ & $\begin{array}{c}.636 \\
(.000)\end{array}$ \\
\hline CYINV & & & & & & & $\begin{array}{c}.469 \\
(.000)\end{array}$ & $\begin{array}{c}.040 \\
(.699)\end{array}$ & $\begin{array}{c}.456 \\
(.000)\end{array}$ & $\begin{array}{l}.324 \\
(.001)\end{array}$ & $\begin{array}{c}.449 \\
(.000)\end{array}$ & $\begin{array}{l}-.504 \\
(.000)\end{array}$ & $\begin{array}{l}-.249 \\
(.014)\end{array}$ \\
\hline AGE & & & & & & & & $\begin{array}{l}.304 \\
(.003)\end{array}$ & $\begin{array}{c}.792 \\
(.000)\end{array}$ & $\begin{array}{l}.436 \\
(.000)\end{array}$ & $\begin{array}{c}.797 \\
(.000)\end{array}$ & $\begin{array}{l}-.324 \\
(.001)\end{array}$ & $\begin{array}{l}-.191 \\
(.062)\end{array}$ \\
\hline SEX & & & & & & & & & $\begin{array}{c}.299 \\
(.003)\end{array}$ & $\begin{array}{c}.215 \\
(.036)\end{array}$ & $\begin{array}{c}.346 \\
(.001)\end{array}$ & $\begin{array}{c}.054 \\
(.605)\end{array}$ & $\begin{array}{c}.164 \\
(.113)\end{array}$ \\
\hline WKY & & & & & & & & & & $\begin{array}{c}.434 \\
(.000)\end{array}$ & $\begin{array}{c}.806 \\
(.000)\end{array}$ & $\begin{array}{l}-.278 \\
(.006)\end{array}$ & $\begin{array}{l}-.103 \\
(.318)\end{array}$ \\
\hline PART & & & & & & & & & & & $\begin{array}{c}.455 \\
(.000)\end{array}$ & $\begin{array}{l}-.359 \\
(.000)\end{array}$ & $\begin{array}{c}-.147 \\
(.153)\end{array}$ \\
\hline CPAY & & & & & & & & & & & & $\begin{array}{l}-.367 \\
(.000)\end{array}$ & $\begin{array}{l}-.007 \\
(.945)\end{array}$ \\
\hline ATMP & & & & & & & & & & & & & $\begin{array}{c}.122 \\
(.238)\end{array}$ \\
\hline
\end{tabular}

* The first number listed is the correlation; the number in parentheses is the significance level 
Table 4

The Eight Factor Solution of the Independent Variables about Control Factors, Client Characteristics and Auditor Characteristics by Taiwan

Factor 1: Effectiveness of control activities (22\%)

\begin{tabular}{l|l}
\hline CA4 & There are effective physical safeguards over assets
\end{tabular}

CA6

CA5

CA8

CA3

CA9

CA2

CA1

CA7

There are appropriate procedures for the review of variances from budgeted performance

.809

There are appropriate duties and responsibilities assigned to the internal auditors

There are effective general Computer Information Systems (CIS) controls

The internal auditors are effective at remedying weaknesses in internal control

There is appropriate segregation of duties for client employees whose work is related to financial matters

There is an appropriate policy for the authorisation of transactions

There are appropriate practices in place to cover the holidays of employees whose work is related to financial

Factor 2: Maturity of respondent (12.27\%)

\begin{tabular}{l|l} 
WKY & Years of auditing experience the respondent has
\end{tabular}

PART Whether the respondent is a partner

AGE Age of the respondent

CPAY For how long the respondent has been a CPA

CYIV Tenure of auditor/client relationship

Factor 3: Effectiveness of environmental monitoring (8.15\%)

\begin{tabular}{|l|l|l|l} 
CA18 & The client is effective at monitoring changes in customer requirements & .811
\end{tabular}

CA17 The client is effective at monitoring competitors' activities

CA19 The audit process usually produces changes in the client's of financial statements

Factor 4: Reporting bias of management $\mathbf{( 5 . 8 4 \% )}$

CA14 The client's major operating decisions are usually made by just one or two individuals

CA13 The client's senior management usually tends to report the most favourable financial picture

Factor 5: Size of client $\mathbf{( 5 . 7 4 \% )}$

\begin{tabular}{|l|l|l|l}
\hline LITD & Whether the respondent client is listed on the Stock Exchange & .688 \\
\hline
\end{tabular}

TAST The respondent client's total assets at end of fiscal year .682

Factor 6: Reliability of management $\mathbf{( 5 . 4 2 \% )}$

CA11 The rate of turnover of senior management has been low in the last three years

.684

Factor 7: Extent of check on financial personnel (5.32\%)

CA15 The client usually investigates the background of new employees whose work is related to financial matters

Factor 8: Size of the audit firm (4.98\%)

\begin{tabular}{l|l} 
BIG 5 & Whether the respondent works for a Big 5 audit firm
\end{tabular}

.760

*All loadings over 0.58 are reported. The extraction method used was Principal Component Analysis and the rotation method was Varimax with Kaiser Normalisation. The rotation converged in twelve iterations. The percentage of the variance explained by the eight components is $69.71 \%$. 
Table 5

The seven Factor Solution of the Independent Variables about Control Factors, Client Characteristics and Auditor Characteristics by Singapore

Factor 1: Effectiveness of control activities (25.52\%)

\begin{tabular}{l|l} 
CA9 & The internal auditors are effective at remedying weaknesses in internal control
\end{tabular}

CA5 There is effective co-ordination between different financial functions (e.g. sales, purchases cash, etc.)

CA4 There are effective physical safeguards over assets

CA8 There are appropriate duties and responsibilities resigned to the internal auditors

CA6 There are appropriate procures for the review of valances from budgeted performance

CA2 There is appropriate segregation of duties for client employees whose work is related to financial matters

CA3 There are effective general Computer Information Systems (CIS) control s

CA1 There is an appropriate policy for the authorisation of transactions

CA7 There are appropriate practices in place to cover the holidays of employees whose work is related to financial matters

CA18 The client is effective at monitoring changes in Customer requirements

Factor 2: Maturity of respondent $\mathbf{( 1 2 . 0 5 \% )}$

\begin{tabular}{|l|l|l|}
\hline WKY & Years of auditing experience the respondent has & .933 \\
\hline
\end{tabular}

CPAY For how long the respondent has been a CPA $\quad .910$

AGE Age of the respondent

\begin{tabular}{l|l} 
PART & Whether the respondent is a partner
\end{tabular}

Factor 3: Extent of check on financial personnel and environmental monitoring $\mathbf{( 8 . 8 0 \% )}$

\begin{tabular}{|l|ll} 
CA15 & The client usually investigates the background of new employees whose work is related to financial matters & .777
\end{tabular}

\begin{tabular}{l|lll} 
CA16 & There are appropriate training programmes for Employees whose work is related to financial matters & .733
\end{tabular}

CA17 The client is effective at monitoring competitors' activities

Factor 4: Large audit firm environment $(\mathbf{8 . 3 5 \%})$

\begin{tabular}{l|l} 
BIG5 & Whether the respondent works for a Big 5 audit firm
\end{tabular}

LITD Whether the respondent client is listed on the Stock Exchange

TAST Respondent client's total asset at end of fiscal year

Factor 5: Reporting bias of management (7.93\%)

\begin{tabular}{|l|l|l|l|}
\hline CA13 & The client's senior management usually tends to report the most favourable financial picture & .848
\end{tabular}

CA14 The client's major operating decisions are usually made by just one or two individuals

CA10 There are strong factors that might motivate senior management to override nesting controls (e.g. tight credit, $\quad .653$

low working capital, bonus plans, need to meet forecast, declining industry, etc.)

CA19 The audit process usually produces changes in the client's draft financial statements

Factor 6: Reliability of management $\mathbf{( 6 . 5 6 \% )}$

\begin{tabular}{|l|l|l|l}
\hline CA11 & The rate of turnover of senior management has been low in the last three years & .725 \\
\hline
\end{tabular}

\begin{tabular}{l|ll} 
CA12 The client's senior management has a good business reputation & .673 \\
\hline
\end{tabular}

Factor 7: Percentage of the respondent's time auditing $(6.32 \%$.)

\begin{tabular}{|l|l|l|l}
\hline ATMP & The approximate percentage of the respondent's time spent on auditing
\end{tabular}

$-.837$

All loadings over 0.55 are reported. The extraction method used was Principal Component Analysis and the rotation method was Varimax with Kaiser Normalisation. The rotation converged in eight iterations. The percentage of the variance explained by the seven components is $75.53 \%$. 
Table 6

Results of the logistic regression model for the high assessed level of audit risk against factor groupings of inherent risk factors, control risk factors and auditor characteristics by Taiwan $\mathrm{AR}=\quad f($ Factor $1+$ Factor $2+$ Factor 3+ Factor $4+$ Factor $5+$ Factor $6+$ Factor $7+$ Factor 8)

Dependent Variable: Audit Risk

\begin{tabular}{|c|c|c|c|c|c|}
\hline Independent variable & Predicted relation & Estimated coefficient & Standard deviation & Wald statistics & P level (two-tailed) \\
\hline Intercept & none & .3232 & .2325 & 1.9324 & .1645 \\
\hline Factor 1 & - & -1.3045 & .3237 & 16.2364 & .0001 \\
\hline Factor 2 & $?$ & .2394 & .2418 & .9807 & .3220 \\
\hline Factor 3 & $?$ & .1393 & .2395 & .3380 & .5610 \\
\hline Factor 4 & + & 6818 & .2581 & 6.9800 & .0082 \\
\hline Factor 5 & + & .1805 & .2294 & .6192 & .4314 \\
\hline Factor 6 & - & -.6172 & .2454 & 6.3238 & .0119 \\
\hline Factor 7 & $?$ & .1210 & .2393 & .2555 & .6132 \\
\hline Factor 8 & $?$ & -.1860 & .2435 & .5835 & .4449 \\
\hline $\begin{array}{l}\text { Number of observation } \\
\text { Chi-Square for model }\end{array}$ & $\begin{array}{l}111 \\
8 \text { degree of fre }\end{array}$ & 37.03 & $\begin{array}{l}\text { Percentage of obser } \\
\text { Pyalue }\end{array}$ & correctly Class & $\begin{array}{l}77.48 \% \\
0000\end{array}$ \\
\hline
\end{tabular}

Table 7

Results of the Logistic Regression Model for the High Assessed Level of Business Risk against Factor Groupings of Inherent Risk Factors, Control Risk Factors and Auditor Characteristics by Taiwan BR $=\mathrm{f} \quad$ (Factor 1+ Factor 2 + Factor 3+ Factor $4+$ Factor $5+$ Factor 6+ Factor 7+Factor 8) Dependent Variable: Business Risk

\begin{tabular}{|c|c|c|c|c|c|}
\hline Independent variable & $\begin{array}{c}\text { Predicted } \\
\text { relation }\end{array}$ & Estimated coefficient & Standard deviation & $\begin{array}{c}\text { Wald } \\
\text { statistics }\end{array}$ & $\begin{array}{c}\text { P level } \\
\text { (one-tailed) }\end{array}$ \\
\hline Intercept & none & -.2224 & .2193 & 1.0290 & .3104 \\
\hline Factor 1 & - & -1.0546 & .2872 & 13.4874 & .0002 \\
\hline Factor 2 & + & .1547 & .2189 & .4996 & .4797 \\
\hline Factor 3 & - & .3091 & .2299 & 1.8077 & .1788 \\
\hline Factor 4 & + & 6708 & .2552 & 6.9084 & .0086 \\
\hline Factor 5 & + & .0116 & .2209 & .0028 & .9581 \\
\hline Factor 6 & - & -.4696 & .2284 & 4.2288 & .0397 \\
\hline Factor 7 & - & -.1769 & .2227 & .6311 & .4270 \\
\hline Factor 8 & + & .1909 & .2277 & .7024 & .4020 \\
\hline Number of observation & 111 & & \multirow{2}{*}{\multicolumn{2}{|c|}{$\begin{array}{l}\text { Percentage of observation correctly Classified } \\
\mathrm{P} \text { value }\end{array}$}} & $69.37 \%$ \\
\hline Chi-Square for model & (8 degree of freedom & 29.25 & & & .0003 \\
\hline
\end{tabular}


Table 8

Results of the Logistic Regression Model for the High Assessed Level of Personal Risk against Factor Groupings of Inherent Risk Factors, Control Risk Factors and Auditor Characteristics by Taiwan PR = f (Factor 1+ Factor 2 + Factor 3+ Factor 4 + Factor $5+$ Factor 6 + Factor 7+Factor 8) Dependent Variable: Personal Risk

\begin{tabular}{cccccc}
\hline Independent variable & Predicted relation & Estimated coefficient & Standard deviation & Wald statistics & P level (one-tailed) \\
\hline Intercept & none & -.9114 & .2595 & 12.3360 & .0004 \\
Factor 1 & - & -1.5572 & .3730 & 17.4338 & .0000 \\
Factor 2 & + & .3827 & .2449 & 2.4407 & .1182 \\
Factor 3 & - & .2744 & .2507 & 1.1980 & .2737 \\
Factor 4 & + & .7115 & .3042 & 5.4720 & .0193 \\
Factor 5 & + & -.1682 & .2712 & .3844 & .5352 \\
Factor 6 & - & -.6215 & .2636 & 5.5576 & .0184 \\
Factor 7 & - & -.3646 & .2590 & 1.9817 & .1592 \\
Factor 8 & + & .2439 & .2595 & .8834 & .3473 \\
\hline Number of observation & 111 & \multicolumn{5}{c}{ Percentage of observation correctly classified } \\
Chi-Square for model (8 degree of freedom) & 40.715 & P value & .0000 \\
\hline
\end{tabular}

Table 9

Results of the Logistic Regression Model for the High Assessed Level of Audit Risk against Factor Groupings of Inherent Risk Factors, Control Risk Factors and Auditor Characteristics by Singapore $\mathrm{AR}=\quad f($ Factor $1+$ Factor $2+$ Factor 3+ Factor $4+$ Factor $5+$ Factor 6+ Factor 7$)$

Dependent Variable: Audit Risk

\begin{tabular}{|c|c|c|c|c|c|}
\hline Independent variable & Predicted relation & Estimated coefficient & Standard deviation & Wald statistics & P level (two-tailed) \\
\hline Intercept & none & 0.5723 & .2820 & 4.1197 & .0424 \\
\hline Factor 1 & - & .7529 & .3281 & 5.2651 & .0218 \\
\hline Factor 2 & none & -.0085 & .2791 & .0009 & .9758 \\
\hline Factor 3 & - & -.1172 & .2929 & .1600 & .6829 \\
\hline Factor 4 & none & -.1566 & .2798 & .3134 & .5756 \\
\hline Factor 5 & + & .1101 & .2825 & .1519 & .6967 \\
\hline Factor 6 & - & -.5288 & .3238 & 2.6667 & .1025 \\
\hline Factor 7 & none & -.1879 & .2816 & .4454 & .5045 \\
\hline Number of observatio & 64 & & \multirow{2}{*}{\multicolumn{2}{|c|}{$\begin{array}{l}\text { Percentage of observation correctly Classified } \\
\text { P value }\end{array}$}} & $65.63 \%$ \\
\hline Chi-Square for model & 7 degrees of freedom & 9.934 & & & 0.1923 \\
\hline
\end{tabular}

Table 10

Results of the Logistic Regression Model for the High Assessed Level of Business Risk against Factor Groupings of Inherent Risk Factors, Control Risk Factors and Auditor Characteristics by Singapore $\mathrm{BR}=\quad f($ Factor $1+$ Factor $2+$ Factor $3+$ Factor $4+$ Factor $5+$ Factor $6+$ Factor 7$)$ Dependent Variable: Business Risk

\begin{tabular}{|c|c|c|c|c|c|}
\hline Independent variable & Predicted relation & Estimated coefficient & Standard deviation & Wald statistics & P level (one-tailed) \\
\hline Intercept & none & .5441 & .2700 & 4.0604 & .0439 \\
\hline Factor 1 & - & $.444 \circ 7$ & .2924 & 2.3132 & .1283 \\
\hline Factor 2 & + & .0130 & .2690 & .0023 & .9614 \\
\hline Factor 3 & - & -.3314 & .2997 & 1.2225 & .2689 \\
\hline Factor 4 & + & -.0205 & .2708 & .0057 & 9397 \\
\hline Factor 5 & + & .0423 & .2668 & .0251 & .8740 \\
\hline Factor 6 & - & -.3525 & .2936 & 1.4414 & .2299 \\
\hline Factor 7 & + & -.0230 & .2722 & .0072 & .9326 \\
\hline Number of observatio & 64 & & \multicolumn{2}{|r|}{ on correctly Classi } & $68.75 \%$ \\
\hline Chi-Square for model & 7 degrees of freedon & 5.048 & \multicolumn{2}{|l|}{$P$ value } & .6541 \\
\hline
\end{tabular}


Table 11

Results of the Logistic Regression Model for the High Assessed Level of Personal Risk against Factor Groupings of Inherent Risk Factors, Control Risk Factors and Auditor Characteristics by Singapore $\mathrm{PR}=\quad f$ (Factor $1+$ Factor $2+$ Factor $3+$ Factor $4+$ Factor $5+$ Factor $6+$ Factor 7$)$

Dependent Variable: Personal Risk

\begin{tabular}{|c|c|c|c|c|c|}
\hline Independent variable & Predicted relation & Estimated coefficient & Standard deviation & Wald statistics & P level (one-tailed) \\
\hline Intercept & none & -.3240 & .2764 & 1.3742 & .2411 \\
\hline Factor 1 & - & .8085 & .3323 & 5.9183 & .0150 \\
\hline Factor 2 & + & .1707 & .2688 & .4033 & .5254 \\
\hline Factor 3 & - & .0285 & .2727 & .0110 & .9167 \\
\hline Factor 4 & + & -.0272 & .2711 & .0101 & .9199 \\
\hline Factor 5 & + & .2607 & .2731 & .9118 & .3396 \\
\hline Factor 6 & - & .1281 & .2835 & .2043 & .6513 \\
\hline Factor 7 & + & .0327 & .2693 & .0147 & .9034 \\
\hline Number of observation & 64 & & \multicolumn{2}{|c|}{ Percentage of observation correctly Classifi } & $67.19 \%$ \\
\hline Chi-Square for model & 7 degrees of freedom & a) 8.883 & \multicolumn{2}{|l|}{$P$ value } & .2612 \\
\hline
\end{tabular}

Table 12

Results of the Mann-Whitney Test for Differences in the Audit, Business, and Personal Risk Assessment between Singapore and Taiwan

\begin{tabular}{|llllll|}
\hline Risk & Country & Mean rank & Sum of ranks & Z value & $\begin{array}{r}\text { Significance } \\
\text { (2-tailed) }\end{array}$ \\
\hline AR & Singapore & 122.42 & 11752.50 & -0.669 & 0.503 \\
& Taiwan & 116.67 & 16450.50 & & \\
\hline BR & Singapore & 128.57 & 12343.00 & -1.860 & 0.063 \\
& Taiwan & 112.48 & 15860.00 & & \\
& Singapore & 120.25 & 11544.00 & -0.240 & 0.811 \\
\hline & Taiwan & 118.15 & 16659.00 & & \\
& & & & & \\
& & & & & \\
\end{tabular}

Table 13

Results of the Wilcoxon Test for Differences in Assessments of Business Risk and Personal Risk

\begin{tabular}{|llllll|}
\hline Country & Ranks & Mean rank & Sum of ranks & Z value & $\begin{array}{l}\text { Significance } \\
\text { (2-tailed) }\end{array}$ \\
\hline Singapore & Negative* $^{*} 21.76$ & 805.00 & -4.594 & 0.000 \\
\cline { 2 - 5 } & Positive** & 19.60 & 98.00 & \\
Taiwan & Negative & 27.38 & 1122.50 & -3.464 & 0.001 \\
\cline { 2 - 4 } & Positive & 27.88 & 362.50 & \\
\hline
\end{tabular}

* Personal risk < Business risk

** Personal risk $>$ Business risk 


\section{APPENDIX}

Please choose the largest audit client in your current portfolio of clients to be use as the example audit client for this questionnaire and answer the questions in section $\mathbf{I}$ and $\mathbf{I I}$ in relation only to this example audit client

I. The following questions relate to characteristics of your example audit client. Please circle a number (e.g. (1)) to indicate the most appropriate answer.

1. Is this client listed on the Singapore Stock Exchange?
1. Yes
2. No

2. Which of following best describes who holds the majority of the shares in this client?

1. Institutional and individual investors in Singapore

2. A Singapore holding company

3. The Singapore government

4. An overseas holding company

3. How large was this client's operation in terms of total assets?
1. Below $\mathrm{S} \$ 1$ million
4. $S \$ 10.1-20$ million
7. $\$ \$ 301-600$ million
2. $\mathrm{S} \$ 1$ - 3 million
5. $\mathrm{S} \$ 20.1-100$ million
8. S\$ 601-1000million
3. S\$ $3.1-10$ million
6. $\$ \$ 101-300$ million
9. Over $\mathbf{S} \$ 1000$ million

4. How large was this client's operation in terms of annual sales?
1. Below $\mathrm{S} \$ 2$ million
4. $\$ \$ 30.1-50$ million
7. $\$ \$ 401-1000$ million
2. $\mathrm{S} \$ 2$ - 10 million
5. $\mathrm{S} \$ 50.1-100$ million
8. S\$ 1001- 3000 million
3. $\mathrm{S} \$ 10.1-30$ million
6. S\$ $101-400$ million
9. Over $\mathrm{S} \$ 3000$ million

5. In which industry is this client?
1. Financial services
3. Manufacturing
2. Utilities
4. Construction
5. Other, please specify

6. For how many years have you been involved in the audit of this client?
1. $1-2$ year
4. $7-8$ years
7. $13-14$ years
2. $3-4$ year
5. $9-10$ years
8. $15-16$ years
3. $5-6$ year
6. $11-12$ years
8. Over 16 years 


\section{The following questions relate to the control environment of your example audit client.}

A. Please circle a number to indicate the extent to which you agree or disagree with each statement of the control attributes with respect to your example audit client. If the statement is not applicable to your example audit client, please circle (8).

1. There is an appropriate policy for the authorization of transactions.

2. There is appropriate segregation of duties for client employees whose work is related

3. There are effective general Computer Information Systems (CIS) controls.

4. There are effective physical safeguards over assets.

5. There is effective co-ordination between different financial function. (e.g. sales, purchases, cash, ect.)

6. There are appropriate procedures for the review of variances from budgeted performance.

7. There are appropriate practices in place to cover the holidays of employees whose work is related to financial matters.

8. There are appropriate duties and responsibilities assigned to internal auditors.

9. The internal auditors are effective at remedying weaknesses in internal control.

10. There are strong factors that night motivate senior management to override existing controls (e.g. tight credit, low working capital, bonus plans, need to meet forecasts, declining industry, etc.)

11. The rate of turnover of senior management has been low in the last three years.

12. The client's senior management has a good business reputation.

13. The client's senior management usually tends to report the most favorable financial picture.

14. The client's major operating decisions are usually made by just one or two individuals.

15. The client usually investigates the backgrounds of new employees whose work is related to financial matters.

16. There are appropriate training programs for employees whose work is related to financial matters.

17. The client is effective at monitoring competitors' activities.

18. The client is effective at monitoring changes in customer requirements.

19. The audit process usually produces changes in the client's draft financial statements.

\begin{tabular}{|c|c|c|c|c|c|c|c|}
\hline \multicolumn{2}{|c|}{$\begin{array}{l}\text { strongly } \\
\text { disagree }\end{array}$} & \multicolumn{3}{|c|}{ neutral } & \multicolumn{2}{|c|}{$\begin{array}{l}\text { strongly } \\
\text { agree }\end{array}$} & $\begin{array}{c}\mathrm{N} / \\
\mathrm{A}\end{array}$ \\
\hline 1 & 2 & 3 & 4 & 5 & 6 & 7 & 8 \\
\hline 1 & 2 & 3 & 4 & 5 & 6 & 7 & 8 \\
\hline 1 & 2 & 3 & 4 & 5 & 6 & 7 & 8 \\
\hline 1 & 2 & 3 & 4 & 5 & 6 & 7 & 8 \\
\hline 1 & 2 & 3 & 4 & 5 & 6 & 7 & 8 \\
\hline 1 & 2 & 3 & 4 & 5 & 6 & 7 & 8 \\
\hline 1 & 2 & 3 & 4 & 5 & 6 & 7 & 8 \\
\hline 1 & 2 & 3 & 4 & 5 & 6 & 7 & 8 \\
\hline 1 & 2 & 3 & 4 & 5 & 6 & 7 & 8 \\
\hline 1 & 2 & 3 & 4 & 5 & 6 & 7 & 8 \\
\hline 1 & 2 & 3 & 4 & 5 & 6 & 7 & 8 \\
\hline 1 & 2 & 3 & 4 & 5 & 6 & 7 & 8 \\
\hline 1 & 2 & 3 & 4 & 5 & 6 & 7 & 8 \\
\hline 1 & 2 & 3 & 4 & 5 & 6 & 7 & 8 \\
\hline 1 & 2 & 3 & 4 & 5 & 6 & 7 & 8 \\
\hline 1 & 2 & 3 & 4 & 5 & 6 & 7 & 8 \\
\hline 1 & 2 & 3 & 4 & 5 & 6 & 7 & 8 \\
\hline 1 & 2 & 3 & 4 & 5 & 6 & 7 & 8 \\
\hline 1 & 2 & 3 & 4 & 5 & 6 & 7 & 8 \\
\hline
\end{tabular}

B. Please circle a number to indicate your assessment of the following risks relating to your example audit client.

1. The audit risk presented by this client

2. The business risk presented to your firm by this client

3. The risk of damage to your personal reputation from being associated with the audit of this client

$\begin{array}{ccccccc}\begin{array}{c}\text { extremely } \\ \text { low }\end{array} & \text { Very low } & \text { low } & \text { moderate } & \text { high } & \begin{array}{c}\text { very } \\ \text { high }\end{array} & \begin{array}{c}\text { extremely } \\ \text { high }\end{array} \\ 1 & 2 & 3 & 4 & 5 & 6 & 7 \\ 1 & 2 & 3 & 4 & 5 & 6 & 7 \\ 1 & 2 & 3 & 4 & 5 & 6 & 7\end{array}$




\section{The following questions refer to some facts about yourself and your firm}

1. What is your age?
1. Under 20 years
2. $20-24$ years
3. $25-29$ years
4. $30-34$ years
5. $35-39$ years
6. $40-44$ years
7. $45-49$ years
8. $50-54$ years
$9.55-59$ years
10. 60 years or more

2. What is your sex

1. Male 2. Female

3. What is your highest degree
1. Associate degree
3. Master's degree
2. Bachelor's degree
4. Doctor's degree

4. How many years of auditing experience do you have?
1. $1-3$ years
5. $13-15$ years
2. $4-6$ years
3. $7-9$ years
6. $16-18$ years
7. $19-21$ years
4. $10-12$ years
8. 22 years or more

5. What is your position in your firm?
1. Partner
2. Manager
3. In-charge senior
4. Other, please specify

6. What language do you usually speak at home?

1. Mandarin(including dialect)

2. Malay

3. Indian

4. English

5. Other, please specify

7. For how long have you been a CPA?
1. Not yet qualified
5. $10-12$ years
2. $1-3$ years
3. 4-6 years
6. $13-15$ years
4. $7-9$ years
7. $16-18$ years
8. 19 years or more

8. Please indicate the approximate percentage of your working time spent on auditing
1. $0-20 \%$
4. $61-80 \%$
2. $21-40 \%$
5. $81-100 \%$
3. $41-60 \%$

9. Which of the following best describes your firm?

1. Big Five or affiliate

2. Medium sized international or affiliate

3. Other, please specify 


\section{REFERENCES}

1. _ Singapore Standard on Auditing No. 11 - Fraud and Error (ICPAS, 1995).

2. $\longrightarrow$ Singapore Standard on Auditing No. 30 - Knowledge of the Business (ICPAS, 1995).

3. Anderson, J.C., Johnson, E.N. \& Reckers, P.M. (1994). Perceived Effects of Gender, Family Structure, and Physical Appearance on Career Progression in Public Accounting: A Research Note, Accounting, Organizations and Society, 19(6), pp. 483-491.

4. $\quad$ Apostolou B. A., Hassell J. M., Webber S. A., \& Sumners G. E. (2001). The Relative Importance of Management Fraud Risk Factors, Behavioral Research in Accounting, 13, pp. 1-24.

5. ARDF (The Accounting Research and Development Foundation), Statement on Auditing Standards of Taiwan No. 5 - Investigation and Appraisal of Internal Accounting Control (ARDF, 1985).

6. Arens, A. A., Loebbecke, J.K. \& Ambanpola, K.B. (1997). Auditing in Singapore: an integrated approach, Prentice Hall, 2ed.

7. Arnold Sr, D. F., Bernardi, R. A., \& Neidermeyer, P. E. (2001). The association between European materiality estimates and client integrity, national culture, and litigation, The International Journal of Accounting, 36(4), pp. 459-483.

8. Bell, T.B. \& Carcello, J.V. (2000). A Decision Aid for Assessing the Likelihood of Fraudulent Financial Reporting, Auditing: A Journal of Practice and Theory, 19(1), pp. 169-184.

9. Carcello, J.V. \& Palmrose, Z. (1994). Auditor Litigation and Modified Reporting on Bankrupt Clients, Journal of Accounting Research, 32(Suppl.), pp. 1-30.

10. COSO (Committee of Sponsoring Organizations of the Treadway Commission) (1992). Internal Control: Integrated Framework. Harborside, NJ: AICPA.

11. Dalton, R.R., Hill, J.W. \& Ramsay, R.J. (1997). The Treat of Litigation and Voluntary Partner/Manager Turnover in Big Six Firms, Journal of Accounting and Public Policy, 16, pp. 379-413.

12. Davis, L.R. \& Simon, D.T. (1992). The Impact of SEC Disciplinary Actions on Audit Fees, Auditing: A Journal of Practice and Theory, 11(1), pp. 58-68..

13. DeJong, D.V. \& Smith, J.H. (1984). The Determination of audit responsibilities: An Application of Agency Theory. Auditing: A Journal of Practice and Theory, 4(2), pp. 20-34.

14. Evers, H., Schlee, G., Stauth, G. \& Buchholt, H. (1993). Trade Routs, Trust and Trading Networks: Chinese Small Enterprises in Singapore. Verlag breitenbach Publishers.

15. Fanning K., Cogger K. O. \& Srivastava R. (1995). Detection of Management Fraud: A Neural Network Approach, International Journal of Intelligent Systems in Accounting, Finance and Management, 4(3), pp.113-126.

16. Ferguson, M. J. \& Majid, A. (2003). To Sue or Not to Sue: An Experimental Study of Factors Affecting Hong Kong Liquidators Audit Litigation Decisions, Journal of Business Ethics, 46(4), pp. 363-374.

17. Foil, C. M., O'connor \& Aguinis, H. (2001). All for One and One for All? The Development and Transfer of Power across Organizational Levels, Academy of Management Review, 26(2), pp. 224-242.

18. Hackenbrack, K. (1993). The Effect of Experience with Different Sized Clients on Auditor Evaluations of Fraudulent Financial Reporting Indicators, Auditing: A Journal of Practice and Theory, 12 (1), pp. 99-110.

19. Haskins, M.E. \& Dirsmith, M.W. (1993). Control and Inherent Risk Assessments in Client Engagements: An Examination of Their Interdependencies, Journal of Accounting and Public Policy, 14, pp. 63-83.

20. Haskins, M.E. (1987). Client Control Environments: An Examination of Auditors' Perception, The Accounting Review, LXII(3), pp. 542-563

21. Hofstede, G. (1994). Cultures and Organizations: Software of the mind. McGraw-Hill International Limited.

22. Hull, R. P. \& Umansky, P. H. (1997). An examination of gender stereotyping as an explanation for vertical job segregation in public accounting. Accounting, Organisations and Society, 22(6), 507-528.

23. Huss, H.F. \& Jacobs, F.A. (1991). Risk Containment: Exploring Auditor Decision in the Engagement Process, Auditing: A Journal of Practice \& Theory, 10(2), pp. 51-60.

24. Huss, H.F., Jacobs, F.A., Patterson, D.M. \& Park, M. (2000). An Integrative Model of Risk Management in Auditing, American Business Review, (June), pp. 113-121.

25. Institute of Certified Public Accountants of Singapore, Singapore Standard on Auditing No. 6 - Risk Assessments and Internal Control (ICPAS, 1995). 
26. Kane, E.J. \& DeTrask, K. (1999). Breakdown of Accounting Controls at Barings and Daiwa: Benefits of Using Opportunity-Cost Measures for Trading Activity, Pacific-Basin Finance Journal, 7, pp. 203-228.

27. Kinney, W.R., Jr. (1989). Achieved Audit Risk and the Audit Outcome Space, Auditing: A Journal of Practice and Theory, 8 (Suppl.), pp. 67-84.

28. Lee, J. (1996). Culture and Management—A Study of Small Chinese Family Business in Singapore, Journal of Small Business Management, 34(3), pp. 63-67.

29. Lennox, C.S. (1999). Audit Quality and Auditor Size: An Evaluation of Reputation and Deep Pockets Hypotheses, Journal of Business Finance and Accounting, 26(7\&8), pp. 779-805.

30. Loebbecke, J.K., Eining, M.M., \& Willingham, J.J. (1989), Auditors’ Experience with Material Irregularities: Frequency, Nature, and Detectability, Auditing: A Journal of Practice and Theory, 9 (1), pp. 1-28.

31. Loft, A. (1992). Accountancy and the Gendered Division of Labour: A Review Essay, Accounting, Organizations and Society, 17(3/4), pp. 367-378.

32. Low, L., Tan, P.H. \& Koh, H. (1990). The Determination of Audit Fees: An Analysis in the Singapore Context, Journal of Business Finance and Accounting, 17(2), pp. 285-295.

33. Lys, T. \& Watts, R.L. (1994). Lawsuits against Auditors, Journal of Accounting Research, 32(Suppl.), pp. 65-93.

34. Marden, R.E., Holstrum, G.L. \& Schneider, S.L. (1997). Control Environment Condition and the Interaction Between Control Risk, Account Type and Management's Assertions, Auditing: A Journal of Practice and Theory, 16(1), pp. 51-68.

35. Palmrose, Z.V. (1987). Litigation and Independent Auditors: The Role of Business Failures and Management Fraud, Auditing: A Journal of Practice and Theory, 6(2), pp. 91-103.

36. Pierre, K.,St. \& Anderson, J.A. (1984). An Analysis of the Factors Associated with Lawsuits Against Public Accountants, The Accounting Review, LIX(2), pp. 242-263.

37. Pratt, J. \& Stice, J.D. (1994). The Effects of Client Characteristics on Auditor Litigation Risk Judgments, Required Audit Evidence, and Recommended Audit Fees, The Accounting Review, 69(4), pp. 639-656.

38. Rollins, T.P. \& Bremser, W.G. (1997). The SEC's Enforcement Actions against Auditors: An Auditor reputation and Institutional Theory Perspective, Critical Perspectives on Accounting, 8, pp. 191-206.

39. Simon, R. (1996). The Barings Blight, Chartered Accountants Journal of New Zealand, 75(2), p. 39.

40. Simunic, D.A. \& Stein, M.T. (1990). Audit Risk in a Client Portfolio Context, Contemporary Accounting Research, 6 (2), pp. 329-343.

41. Stice, J.D. (1991). Using Financial and Market Information to Identify Pre-Engagement Factors Associated with Lawsuits Against Auditors, The Accounting Review, 66(3), pp. 516-533.

42. Sullivan, D. J. (1988). Why the Auditing Standards on Evaluating Internal Control Needed to be Replace. Auditing Symposium, 40, 47-54.

43. Tabachnick, B.G. \& Fidell, L.S. (2001). Using Multivariate Statistics. Allyn \& Bacon, 4thed.

44. Tirole, J. (1996). A Theory of Collective Reputations (with Applications to the Persistence of Corruption and to Firm Quality), The Review of Economic Studies Limited, 63, pp. 1-22.

45. Vinten, G. (1991). Risk Management and the Auditor, Managerial Auditing Journal, 6(3), 1991 , p.3.

46. Walker, P. L., Shenkir, W. G.. \& Hunn, C. S. (2001). Developing Risk Skills: An Investigation of Business Risks and Controls at Prudential Insurance Company of America, Issues in Accounting Education, 16 (2), pp. 291.

47. Wanda, W. (2000). Reporting practices: potential lessons from Cendant Corporation, European Management Journal, 18(3), pp. 328-333.

48. Wier, B. \& Hunton, J.E. (1995). Promoting Management Accountants, Management Accounting, 76(11), pp. 47-51.

49. Wilson, T.E., Jr. \& Grimlund, R.A. (1990). An Examination of the Importance of an Auditor's Reputation, Auditing: A Journal of Practice and Theory, 9(2), pp. 43-59. 